\title{
INOVASI KEBIJAKAN KEPALA SEKOLAH DALAM PENGEMBANGAN KURIKULUM TINGKAT SATUAN PENDIDIKAN (KTSP) UNTUK MENUMBUHKAN SIKAP SOSIAL PESERTA DIDIK DI ERA REVOLUSI INDUSTRI 4.0
}

\author{
Koko Adya Winata ${ }^{1}$, Tatang Sudrajatt ${ }^{2}$ Fitri Handayani ${ }^{3}$, Qiqi Yuliati \\ Zaqiah $^{4}$ \\ ${ }^{1}$ Universitas Sangga Buana Bandung Indonesia \\ ${ }^{2}$ USB Bandung Indonesia \\ 3,4 UIN SGD Bandung, Indonesia \\ 1adyawinata@gmail.com
}

\begin{abstract}
ABSTRAK
Penelitian ini bertujuan untuk mengkaji tentang inovasi kebijakan kepala sekolah dalam mengembangkan KTSP (Kurikulum Tingkat Satuan Pendidikan) untuk menumbuhkan sikap social peserta didik di era revolusi industry 4.0. Penelitian ini menggunakan metode kualitatif deskriptif. Sumber data penelitian adalah kepala sekolah, guru, peserta didik dan dokumen sekolah. Data dikumpulkan melalui metode observasi, dokumentasi dan wawancara. Kemajuan teknologi informasi sebagai akibat dari revolusi industri 4.0 telah merubah tatanan kehidupan masyarakat termasuk peserta didik. Adanya kecenderungan peserta didik yang kurang peduli social, egois dan tidak ramah terhadap lingkungannya harus segera diatasi melalui inovasi kebijakan kurikulum di sekolah. Inovasi kebijakan kepala sekolah merupakan cara dan metode baru yang diterapkan oleh kepala sekolah dalam upaya untuk meningkatkan mutu lulusan yang memiliki sikap social yang baik. Hasil temuan dalam penelitian ini dapat disimpulkan bahwa inovasi kebijakan kepala sekolah dalam mengembangkan KTSP untuk menumbuhkan sikap social peserta didik melalui; 1) Penyamaan pola pikir terhadap tata kelola kurikulum. 2) Perluasan materi sikap social dan 3) Penguatan proses pembelajaran sikap social.

Kata Kunci: Inovasi Kebijakan Kepala sekolah, Kurikulum, Sikap Sosial Peserta didik, Era Revolusi 4.0
\end{abstract}


Jurnal Pendidikan Pancasila dan Kewarganegaraan

Volume I Nomor 2 (November) 2020

\begin{abstract}
This study aims to examine the principal's policy innovation in developing KTSP (Education Unit Level Curriculum) to foster students' social attitudes in the era of the industrial revolution 4.0. This research uses the descriptive qualitative method. Sources of research data are school principals, teachers, students, and school documents. Data were collected through observation, documentation, and interviews. Advances in information technology due to the 4.0 industrial revolution have changed the order of life for people, including students. Students' tendency to be less socially concerned, selfish, and unfriendly to their environment must be addressed through innovative curriculum policies in schools. Principal's policy innovation is a new method and method applied by school principals to improve the quality of graduates with good social attitudes. The findings in this study can be concluded that the principal's policy innovation in developing KTSP is to foster students' social attitudes through; 1) Equal mindset towards curriculum governance. 2) Expansion of the material for social attitudes and 3) Strengthening the learning process of social attitudes.

Keywords: Principal's Policy Innovation, Curriculum, Students' Social Attitudes. Era Revolution 4.0
\end{abstract}

\title{
PENDAHULUAN
}

Kepala sekolah harus mampu membangun iklim dan sistem pendidikan yang efektif di lingkungan sekolah yang dipimpinnya dengan senantiasa melahirkan gagasan inovatif yang dituangkan dalam sebuah kebijakan di sekolah. Inovasi kebijakan kepala sekolah harus menciptakan sistem pendidikan yang efektif, bermutu, kreatif, inovatif dan berkarakter serta mampu mengadaptasi dan menselaraskan terhadap munculnya perkembangan teknologi yang sangat cepat sebagai dampak dari revolusi industry 4.0. Menurut Sutarno (2012:134-135) inovasi didefinisikan sebagai cara-cara baru dalam pengaturan kerja, dan dilakukan dalam sebuah organisasi untuk mendorong dan mempromosikan keunggulan kompetitif. Inovasi kebijakan sekolah merupakan cara dan metode baru yang diterapkan oleh kepala sekolah dalam upaya untuk meningkatkan mutu lulusan peserta didik yang memiliki karakter mumpuni dan keterampilan teknologi yang tepat guna. Untuk menghadapi tuntutan tersebut, kepala sekolah harus memiliki kemampuan untuk melakukan terobosan dan inovasi lanjutan agar mengahasilkan lulusan yang bermutu sesuai dengan tuntutan kebutuhan masyarakat dalam berbagai aspek kehidupan dan tetap memiliki sikap social yang baik.

Sikap sosial adalah mampu bekerja sama, dapat bersaing secara positif, mampu berbagi pada yang lain, memiliki hasrat terhadap 
Jurnal Pendidikan Pancasila dan Kewarganegaraan

Volume I Nomor 2 (November) 2020

penerimaan sosial, bergantung secara positif pada orang lain, dan memiliki sikap kelekatan (attachment behavior) yang baik (Lydia, 2012: 99). Kepala Sekolah merupakan pimpinan di lembaga pendidikan yang sangat penting kedudukannya dalam memimpin, mengarahkan, mengatur dan menggerakkan organisasi sekolah agar tujuan pendidikan sesuai dengan visi yang sudah ditetapkan. Kedudukan kepala Sekolah memiliki peran tersendiri terhadap langkah kebijakan sekolah yang akan ditetapkan dalam upaya peningkatan kualitas lulusan peserta didik. Pengaruh kepala sekolah dalam meningkatkan mutu sekolah yang dipimpinnya dapat dilakukan melalui pengambilan kebijakan yang dipandang sangat strategis. Kebijakan adalah aturan tertulis yang merupakan keputusan formal organisasi, yang bersifat mengikat, yang mengatur perilaku dengan tujuan untuk menciptakan tata nilai baru dalam masyarakat. ( William N Dunn, 2003: 6). Kebijakan kepala sekolah akan menjadi rujukan utama para guru dalam merencanakan dan melaksanakan proses pembelajaran di kelas. Kepala sekolah sebagai pimpinan di sekolah harus mampu menunjukkan peran dan tugasnya sebagai manajer dengan membuat kebijakan pendidikan yang efektif.

Kebijakan kepala sekolah merupakan kebijakan dalam pendidikan yang berfungsi untuk menjabarkan visi dan misi dari pendidikan dalam masyarakat sekolah tersebut. Kepala sekolah sebagai pemimpin pendidikan harus dapat mengenal, memahami dan mengerti berbagai kondisi yang diinginkan oleh guru maupun warga sekolah lainnya agar kebijakan yang diterapkan di sekolah dapat terlaksana dengan baik. Kepala sekolah harus memiliki wawasan ke depan (visi) dan tahu tindakan apa yang harus dilakukan (misi) serta paham benar cara yang akan ditempuh (strategi), memiliki kemampuan mengkoordinasikan dan menserasikan seluruh sumberdaya terbatas yang ada untuk memenuhi kebutuhan sekolah yang umumnya tidak terbatas, memiliki kemampuan pengambilan keputusan dengan terampil, memiliki kemampuan memobilisasi sumberdaya yang ada untuk mencapai tujuan. (Kodiran, 147: 2017) Era revolusi industri 4.0 telah mempengaruhi sikap social peserta didik. Setiap orang akan sangat sibuk dengan HP, Gadjet dan piranti lunaknya sehingga terdegradasi kepedulian terhadap sosialnya.

Revolusi industri telah mengubah pola pikir dan pola hidup manusia diberbagai sector termasuk dibidang pendidikan. Kemajuan teknologi informasi telah mengakibatkan terjadinya perubahan yang sangat fundamental dengan bercirikan kehidupan yang serba digital. Prilaku kehidupan manusia baik di sector ekonomi, politik, social dan pendidikan 
mengalami perubahan pola hidup yang sangat siginifikan menjadi terintegrasi dengan dunia internet. Dengan perkembangan teknologi informasi yang berkembang secara pesat telah mengalami terobosan diantaranya di bidang artificiall intellegent, dimana teknologi komputer telah mengadopsi keahlian seseorang kedalam suatu aplikasi yang berbasis teknologi dan melahirkan teknolologi informasi dan proses produksi yang dikendalikan secara otomatis (Hamdan, 2018). Akibat dari internet of things dan media social yang mudah diakses penyebaran informasi menjadi tidak terkendali. Oleh karena itu, kunci dalam menghadapi Revolusi Industri 4.0 adalah selain menyiapkan kemajuan teknologi, di sisi lain perlu dilakukan pengembangan sumber daya manusia dari sisi humaniora agar dampak negatif dari perkembangan teknologi dapat ditekan (Banu Prasetyo dan Umi Trisyant, tth). Kemajuan teknologi informasi sebagai akibat dari revolusi industri 4.0 telah merubah tatanan kehidupan masyarakat. Internet telah menjadi sarana media yang sangat massif dan telah dirasakan dampaknya bagi kehidupan.

Peserta didik dalam menggunakan fasilitas internet masih belum banyak yang mampu memilah dan memilih terhadap aktivitas internet yang bermanfaat. Kondisi ini dapat mempengaruhi sikap social peserta didik yang kurang baik. Inovasi dan pengembangan kurikulum sangat penting termasuk di dalam sistem pengajaran. Dengan adanya pengembangan dalam komponen proses pembelajaran dapat berdampak terhadap adanya perubahan sikap positif pada diri peserta didik. Inovasi kebijakan kepala sekolah dalam pengembangan kurikulum sangat diperlukan adanya, sehubungan dengan peningkatan terhadap mutu lulusan yang dibutuhkan oleh masyarkat. Kepala sekolah yang ingin melakukan pengembangan kurikulum harus memahami konsep-konsep kurikulum yang tepat sehingga dapat melahirkan ide, gagasan dan inovasi baru tentang kurikulum yang dibutuhkan. Kepala sekolah harus berinovasi di bidang kurikulum diantaranya dengan menambahkan atau menentukan model pembelajaran dan media pembelajaran yang harus dilakukan oleh guru. Kurikulum menjadi acuan dan rujukan setiap guru untuk merealisasikan visi dan misi sekolah dalam peningkatan sikap social peserta didik. "Social attitudes (sikap sosial) yaitu satu predisposisi atau kecenderungan untuk bertingkah laku dengan cara tertentu terhadap orang lain ( Kartini Kartono, 2010: 469).

Sikap social peserta didik sangat dipengaruhi dari lingkungan dan pengalaman belajarnya. Proses pembelajaran di sekolah sangat mempengaruhi sikap sosial peserta didik. Sikap merupakan hasil dari 
Jurnal Pendidikan Pancasila dan Kewarganegaraan

Volume I Nomor 2 (November) 2020

stimulus yang dilalui pada saat proses belajar atau proses lainnya, sehingga proses belajar ini menentukan sikap seseorang (Yeni, 2014:57). Inovasi kebijakan di bidang kurikulum terkait dengan model pembelajaran, media pembelajaran serta materi pembelajaran merupakan langkah yang harus ditempuh oleh kepala sekolah. Kepala sekolah dalam menentukan kebijakan inovasi kurikulum diharapkan dapat meminimalisir pengaruh negative kemajuan teknologi sebagai dampak dari era revolusi industri 4.0. Adanya kecenderungan peserta didik yang kurang peduli social, egois dan tidak ramah terhadap lingkungannya harus segera diatasi melalui inovasi kebijakan kurikulum di sekolah.

\section{METODE PENELITIAN}

Penelitian ini termasuk jenis penelitian kualitatif deskriptif. Penelitian kualitatif adalah proses pencarian data untuk memahami masalah sosial yang didasari pada penelitian yang menyeluruh (holistik), dibentuk oleh kata kata dan diperoleh dari situasi yang alamiah (Afifuddin dkk, 2012: 84). Dengan menggunakan pendekatan kualitatif diharapkan peneliti dapat lebih leluasa dalam memahami, mengamati dan melakukan penelaahan lebih akurat berkenaan dengan inovasi kebijakan kepala sekolah dalam pengembangan KTSP (Kurikulum Tingkat Satuan Pendidikan) untuk menumbuhkan sikap social peserta didik di SMA 12 Kota Bandung. Untuk menemukan kebenaran terhadap masalah yang sedang diteliti, maka cara yang dilakukan untuk memperoleh data melalui observasi, wawancara dan dokumentasi. Subjek dari penelitian ini adalah kepala sekolah, guru dan peserta didik.

\section{HASIL DAN PEMBAHASAN}

\section{Inovasi Kebijakan Kepala Sekolah}

Kepala sekolah harus menunjukkan kesungguhannya terhadap pengembangan kurikulum dan proses pembelajaran di sekolahnya. Kegiatan belajar mengajar merupakan inti dari proses pendidikan dan guru merupakan pelaksana utama dalam menerapkan kurikulum di sekolah. Kepala sekolah adalah seorang pemimpin yang memiliki tugas dan tanggung jawab membina dan mengembangkan sekolah, baik berupa moral maupun materil demi mencapai kemajuan sekolah dan mencapai tujuan yang diharapkan oleh orang tua peserta didik, masyarakat, ataupun pemerintah (A. Tabrani Rusyan, 2013: 17). Kepala sekolah berkewajiban untuk mengelola pengembangan kurikulum dan proses pembelajaran yang dapat menghasilkan sikap social yang baik bagi 
Jurnal Pendidikan Pancasila dan Kewarganegaraan

Volume I Nomor 2 (November) 2020

peserta didiknya. Inovasi kurikulum dimaksudkan untuk menjelaskan secara rinci berkenaan dengan peningkatan karakter peserta didik terutama dalam aspek sikap sosialnya. Sekolah harus mampu membentuk karakter siswa yang memiliki kecerdasasan intelektual dan kecerdasan social.

Inovasi kebijakan kepala sekolah SMA 12 Kota Bandung dalam upayanya untuk meningkatkan sikap social peserta didik di era revolusi industry melalui pengembangan kurikulum tingkat satuan pendidikan (KTSP). Dalam Standar Nasional Pendidikan (SNP Pasal 1, ayat 15) dikemukakan bahwa Kurikulum Tingkat Satuan Pendidikan (KTSP) adalah kurikulum operasional yang disusun dan dilaksanakan oleh masing-masing satuan pendidikan dengan memperhatikan dan berdasarkan standar kompetensi serta kompetensi dasar yang dikembangkan oleh Badan Standar Nasional Pendidikan (BNSP). Sebagai rujukan dan pijakan utama dalam penyusunan KTSP adalah (1) peningkatan iman dan takwa serta akhlak mulia, (2) peningkatan potensi, kecerdasan, dan minat sesuai dengan tingkat perkembangan dan kemampuan peserta didik, (3) keragaman potensi dan karakteristik daerah dan lingkungan, (4) tuntutan pembangunan daerah dan nasional, (5) tuntutan dunia kerja, (6) perkembangan ilmu pengetahuan, teknologi, dan seni, (7) agama, (8) dinamika perkembangan global, (9) persatuan nasional dan nilai-nilai kebangsaan, (10) kondisi sosial budaya masyarakat setempat, (11) kesetaraan jender, (12) karakteristik satuan pendidikan (BSNP, 2007).

\section{Dampak Era Revolusi Industri 4.0}

Era revolusi industri 4.0 telah mempengaruhi sikap social peserta didik. Setiap orang akan sangat sibuk dengan HP, Gadjet dan piranti lunaknya sehingga terdegradasi kepedulian terhadap sosialnya. Revolusi industri 4.0 telah meninggalkan persoalan baru yang berkaitan dengan hilangnya nilai-nilai sosial humaniora. Generasi milenial, generasi yang lahir pada sekitar tahun 1990-2000an, sudah menunjukkan adanya gejalagejala degradasi mental. Gaya hidup konsumerisme, kebebasan yang tanpa batas, kurang peduli social, sulitnya berinteraksi soal serta hilangnya perilaku etis di media sosial adalah serangkaian contoh dari degradasi tersebut. Kemampuan peserta didik untuk berinteraksi dan bersosialisasi dengan lingkungan menjadi sulit sehubungan dengan komunikasi langsung digantikan dengan komunikasi melalui media social. Internet telah mengambil peran seluruh aspek kehidupan termasuk 
Jurnal Pendidikan Pancasila dan Kewarganegaraan

Volume I Nomor 2 (November) 2020

dalam berkomunikasi. Peserta didik mengalami kecemasan berkomunikasi tatap muka sebagai dampak dari era revolusi 4.0. Mengabaikan lingkungan social adalah merupakan akibat negatif dari era revolusi 4.0. Prilaku negative tersebut harus segera ditanggulangi dan diminimalisir oleh berbagai pihak. Untuk menanggulangi dapak negative tersebut harus dilakukan inovasi kebijakan kepala sekolah di bidang kurikulum yang dapat menumbuhkan sikap social peserta didik.

Kebiasaan setiap siswa membawa HP termasuk di lingkungan sekolah telah menjadi fenomena kekinian. Peserta didik mengekpresikan sikapnya melalui media social dimana kecanggihan teknologi tidak dapat terpisahkan dari kehidupan sehari-hari yang mereka lakukan Media sosial juga dipergunakan untuk mencari sarana hiburan misalnya bermain game atau menyalurkan hobi seperti fotografi atau minat seputar gadget terkini. Masa pencarian identitas diri remaja tidak terlepas dari gaya hidup yang dikembangkan masyarakat terutama dalam mengisi waktu luang, misalnya yang dilakukan para remaja untuk mengakses media sosial. Sebagai contohnya adalah Facebook. Situs pertemanan ini bisa membawa pengaruh negatif jika tidak menyikapinya dengan benar. (Elsa Puji Juwita, dkk., Tth) Akses mudah terhadap internet merupakan salah satu dari ciri revolusi 4.0. dalam bersosialisasi..Peserta didik di lingkungan SMA Negeri 12 Kota Bandung dengan sangat mudahnya mengakses jejaring sosial sehingga dengan bebas berkomentar serta menyalurkan pendapatnya tanpa ada kekhawatiran.

Media sosial telah memberi kebebasan untuk berekspresi melalui komentar yang tidak memiliki batasan ruang dan waktu. Setiap orang dapat berkomunikasi dan berinteraksi sesaui dengan keinginannya. Keberadaan jejaring sosial mempunyai pengaruh yang sangat besar dalam kehidupan seseorang termasuk peserta didik. Prilaku negative di media social sepertinya menjadi fenomena yang sudah menghawatirkan. Memalsukan jati diri dan munculnya kejahatan adalah bagian dari dampak negatif media social. Dampak seperti itu kalau tidak dipahamkan kepada peserta didik dapat menimbulkan preseden buruk bagi pendidikan. Dampak negatif jejaring sosial tersebut, Ketika seseorang terlalu asyik dengan jejaring sosial di dunia maya dan hingga melupakan dunia nyatanya, Mereka merasa lebih leluasa, leluasa dan nyaman menyampaikan pendapat dan juga perasaan mereka di dalam jejaring sosial. Sehingga mereka justru kelihatan murung setiap hari.( Satria MA Koni, 2016:37) 
Jurnal Pendidikan Pancasila dan Kewarganegaraan

Volume I Nomor 2 (November) 2020

\section{Langkah Inovasi Kebijakan Kepala Sekolah Dalam Pengembangan KTSP}

Langkah yang dilakukan kepala sekolah SMA 12 Kota Bandung dalam mengembangkan kurikulum tingkat satuan pendidikan melalui penataan pola pikir dan tata kelola kurikulum, pendalaman dan perluasan materi dan penguatan proses pembelajaran sikap social peserta didik.

\section{Penataan pola pikir terhadap tata kelola kurikulum}

Kurikulum merupakan komponen utama dalam proses pembelajaran untuk meningkatkan kualitas peserta didik termasuk dalam sikap sosialnya. Kepala sekolah SMA 12 Kota Bandung telah melakukan penataan pola pikir dan tata kelola kurikulum yang dapat meningkatkan pengetahuan dan kesadaran peserta didik terhadap sikap social di era revolusi industry 4.0. Kepala sekolah harus mampu mengkomunikasikan setiap kebijakannya kepada seluruh warga sekolah. Komunikasi kepala sekolah terhadap seluruh warga sekolah merupakan bagian dari penataan pola pikir dalam tata kelola kurikulum. Komunikasi kepala sekolah tersebut dilakukan kepada guru, tenaga kependidikan dan siswa berkenaan pentingnya penguatan sikap social peserta didik yang dituangkan dalam kebijakan inovasi kurikulum. Penyamaan dan penataan pola pikir akan menentukan suksesnya kebijakan yang ditetapkan di sekolah. Pola Pikir atau mindset adalah sekumpulan kepercayaan (belief) atau cara berpikir yang mempengaruhi perilaku dan sikap seseorang, yang akhirnya akan menentukan level keberhasilan hidupnya. (Adi W. Gunawan, 2011).

Dengan adanya pola pikir yang sama tentang pelunya inovasi kurikulum dapat memudahkan upaya pimpinan sekolah terhadap implementasi dari inovasi pengembangan kurikulum di dalam penguatan sikap sosial peserta didik. Masing-masing pihak akan memiliki pemahaman dan pola pikir yang sama berkenaan pentingnya penguatan pembelajaran yang dapat mendukung terhadap peningkatan sikap social peserta didik. Maka setiap pihak akan memiliki tanggung jawab dan kesadaran yang sama terhadap pelaksanaan dari inovasi kebijakan kepala sekolah dalam pengembangan kurikulum. Guru akan memiliki tanggung jawab yang sama terhadap proses kegiatan pembelajaran. Adanya kesepahaman antara kepala dan warga sekolah merupakan factor penting dalam kesuksesan inovasi. 
Jurnal Pendidikan Pancasila dan Kewarganegaraan

Volume I Nomor 2 (November) 2020

\section{Perluasan materi Sikap Sosial}

Pendalaman materi adalah kegiatan yang diberikan guru kepada peserta didik dalam memanfaatkan kelebihan waktu yang dimilikinya sehingga mereka memiliki pengetahuan yang lebih kaya dan keterampilan yang lebih baik. Dalam pelaksanaannya kegiatan pengayaan atau pendalaman dapat dilakukan di luar jam pelajaran (Ismail, 2012) Kegiatan pendalaman materi diarahkan untuk memperluas pengetahuan dan pemahaman terhadap penguatan sikap social peserta didik secara umum. Pendalaman materi yang terkait dengan penguatan sikap social peserta didik yang ditetapkan oleh kepala sekolah SMA 12 Kota Bandung sebagai berikut:

a. Ektrakulikuler pendidikan agama Islam

Kegiatan ekstrakurikuler merupakan aktivitas yang dilaksanakan di luar kelas yang bertujuan untuk membentuk pribadi peserta didik agar memiliki karakter baik yang di dalmnya terkait dengan pemahaman keagamaan, akhlak dan sikap social. Ekstrakurikuler pendidikan agama Islam di SMA 12 Kota Bandung bertujuan untuk meningkatkan kemampuan sikap social peserta didik sehubungan jam mata pelajaran pendidikan agama Islam yang terbatas dalam satu minggunya. Penambahan jam mata pelajaran PAI diharapkan dapat menambah pemahaman peserta didik terhadap nilai-nilai agama yang belum tersampaikan ketika di dalam kelas.

b. Kegiatan PHBI (Peringatan Hari Besar Islam)

Kegiatan peringatan hari besar Islam dapat menanamkan keimanan, ketaqwaan kepada Allah SWT, juga dapat mempererat hubungan persaudaraan dan menumbuhkan sikap social peserta didik. Kegiatan PHBI dilakukan dengan menempatkan peserta didik terlibat langsung di dalamnya, mulai dari perencanaan, pelaksanaan dan penilainnya diakhir kegiatan. Pembentukan kepribadian yang bermoral dan religius atau pribadi yang memiliki keberagamaan (religiusitas), tidak cukup dengan mengandalkan mata pelajaran pendidikan agama yang hanya mendapat alokasi waktu dua atau tiga jam pelajaran pada setiap minggunya.( Ermis Suryana dan Maryamah, 2013)

c. Peduli Bencana

Untuk menumbuhkan sikap empati peserta didik terhadap sesama melalui program kegiatan peduli bencana. Seperti peduli bencana banjir, kebakaran, gunung meletus dan bencana-bencana lain yang terjadi. Kegiatan peduli bencana diyakini dapat menumbuhkan 
Jurnal Pendidikan Pancasila dan Kewarganegaraan

Volume I Nomor 2 (November) 2020

sikap social peserta didik. Dalam hal ini peserta didik terlibat langsung dalam kepanitiaan pengumpulan dana sekaligus sebagai penyumbang dana untuk disumbangkan kepada, sesamanya yang tekena musibah. Pendidikan karakter di lingkungan sekolah dapat diintegrasikan dalam pembelajaran pada setiap mata pelajaran. Materi pembelajaran yang berkaitan dengan norma atau nilai-nilai pada setiap mata pelajaran perlu dikembangkan, dieksplisitkan, dikaitkan dengan konteks kehidupan seharihari. Dengan demikian pembelajaran nilainilai karakter tidak hanya pada tataran kognitif, tetapi menyentuh pada internalisasi dan pengalaman nyata dalam kehidupan peserta didik sehari-hari di masyarakat.( Yuni Maya Sari, 2014:16).

d. Sholat berjamaah

Sholat berjamaah merupakan kegiatan yang ditetapkan oleh kepala sekolah SMA 12 Kota Bandung yang tidak hanya berkenaan dengan sikap religious siswa namun diyakini dapat menumbuhkan sikap sosialnya. Kegiatan sholat berjamaah bukan hanya sekedar bukti keimanan kepada perintah sang Kholik tapi mengandung unsur social, yakni kebersamaan, silaturahmi dan saling mengenal diantara peserta didik semakin terkuatkan. Penanaman nilai agama termasuk di dalamnya pembiasaan nilai-nilai shalat berjamaah dapat berkembang pada diri siswa dan diaplikasikan dalam kehidupan sehari-hari.

\section{Penguatan Proses Pembelajaran Sikap Sosial}

Penguatan sikap social Di SMA Neger 12 Kota Bandung dilakukan dengan prosess pembelajaran yang bersifat integratif. Proses integrasi sikap sosial dilakukan oleh guru di kegiatan pendahuluan dengan cara guru memberikan pemodelan, penugasan, arahan, peringatan dan larangan melalui contoh-contoh fenomena yang ada dalam kehidupan sehari-hari terkait dengan materi himpunan.( Endah Asmarawat, dkk., 58: 2016). Peserta didik diajak untuk memahami fenomena yang terjadi di masyarakat terkait dengan kepedulian social yang kemudian didiskusikan di kelas. Model pembelajaran yang dilakukan dengan menggunakan studi kasus dimana hal itu akan memberi pemahanan dan penguatan kesadaran akan pentingnya sikap social.Penguatan sikap social 
peserta didik dilakukan oleh guru melalui proses pembelajaran yang memberi pengetahuan dan kesadaran melaui contoh kasus dan pemodelan. Studi kasus menjadi salah satu bagian dari kreatifitas pembelajaran dalam meningkatkan kesadaran social peserta didik. Pendidikan pada hakikatnya memiliki tujuan untuk mengembangkan kehidupan siswa, khususnya sebagai anggota masyarakat yang dapat dicapai dengan upaya berikut: (Rismawanti, edisi 4: 2017)

a. Memperkuat kesadaran untuk hidup bersama di masyarakat.

Memberikan pemahaman terhadap peserta didik akan pentingnya hidup bersama di masyarakat. Manusia sebagai makhluk social harus mampu mengembangkan sikap peduli, berempati, bersimpati dan berkeinginan untuk menjaga pergaulan yang harmonis di lingkungannya. Memperkuat kesadaran untuk hidup bersama di masyarakat dapat ditempuh melalui pembiasaan kebersamaan, saling menghormati, menghargai dan saling membantu. Peserta didik diberi pemahaman sekaligus pembiasaan mengenai pentingnya hidup bersama di masyarakat. Maka diperlukan kemampuan berkomunikasi secara jelas, lugas, dan meyakinankan yang dapat mengatasi adanya perbedaan pendapat bahkan konflik akibat perbedaan pemahaman tentang sesuatu hal. Komunikasi yang dibangun di masyarakat dapat mengantarkan adanya kesadaran untuk menciptakan kebersamaan. Dalam memperkuat kesadaran untuk hidup bersama dengan orang lain peserta didik diajarkan untuk memiliki sikap empati dan peduli sesama dengan memiliki kecakapan komunikasi. Empati, sikap penuh pengertian dan seni berkomunikasi dua arah, perlu ditekankan karena berkomunikasi tidak sekedar menyampaikan pesan, tetapi isi dan sampainya pesan disertai dengan kesan baik yang menumbuhkan hubungan harmonis. (Elia Flurentin, tth).

b. Menumbuhkan rasa tanggung jawab social.

Peserta didik harus diberi pemahaman tentang pentingnya tanggung jawab dalam segala hal termasuk di lingkungan masyarakatnya. Tanggung jawab sosial merupakan sikap social berkaitan dengan eksistensi sesorang sebagai bagian dari masyarakatnya melalui sikap peduli dan kerjasama.. Tanggung jawab sosial berarti memelihara dengan baik sesuatu di sekeliling kita serta kesediaan untuk melakukan sesuatu yang perlu dilakukan. (Febriana Florentina Keke, 2014: 350) Peserta didik diharapkan memiliki kesadaran tindakan yang diwujudkan 
dengan sikap saling menghormati dan menjunjung tinggi kebersamaan dan saling mengasihi antara sesama. Bentuk tanggung awab social dapat ditunjukkan dengan adanya kesadaran sebagai bagian dari masyarakat social. Hal itu telihat manakala peserta didik dapat bersikap dengan senantiasa memelihara hak orang lain dan selalu mengedepankan kepentingan bersama serta menjaga keharmonisan social. Sikap untuk menjaga persaudaran dan kebersamaan senantiasa dijaga dengan baik melalui prilaku yang mengedepankan kesopanan dan keramahan ketika bergaul di masyarakat.

c. Memberikan kemampuan bersosialisasi.

Kemampuan bersosialisasi di masyarakat merupakan hal penting yang harus dimiliki oleh peserta didik. Sikap sosial tersebut dapat ditanamkan melalui proses interaksi di kelas maupun di luar kelas. Melalui proses pembelajaran penguatan sikap social peserta didik dapat menjadi pribadi yang tidak minder ketika bergaul di masyarakat. Kemampuan bersosialisasi dapat terlihat manakala siswa aktif dengan teman kelasnya membangun komunikasi dan kerjasama baik dalam hal kegiatan kelas maupun kegiatan lainnya. Dengan demikian menumbuhkan social peserta didik harus diawali dari proses pembelajaran yaitu bagaimana guru menumbukan sikap aktif siswa di kelas.

Penguatan pembelajaran sikap social di kelas dilakukan dengan model pembelajaran yang menumbuhkan setiap peserta didik untuk perhatian, peduli dan mencari sosuli dari masalah yang ada. Studi kasus menjadi penting dilakukan untuk mengasah keterampilan siswa dalam memahami masalah dan memecahkan maslah. Dengan demikian sikap social peserta didik dapat terbentuk dengan baik melalui penguatan pembelajaran menggunakan model studi kasus. Guru merupakan komponen yang paling berpengaruh terhadap tercapainya proses dan hasil pendidikan, untuk itu guru harus memiliki kompetensi yang baik. Oleh karena itu perbaikan kurikulum yang dilakukan untuk meningkatkan kualitas pendidikan nasional tidak lepas dari peran guru yang profesional dan berkualitas (Mulyasa,2011:5).

\section{KESIMPULAN}

Era revolusi industri 4.0 telah mempengaruhi sikap social peserta didik. Setiap peserta didik akan sangat sibuk dengan HP, Gadjet dan 
piranti lunaknya sehingga terdegradasi kepedulian terhadap sosialnya. Oleh karena itu, diperlukan inovasi kebijakan kepala sekolah yang dapat menumbuhkan karakter peserta didik. Kepala sekolah harus memiliki kemampuan untuk melakukan terobosan dan inovasi lanjutan di bidang kurikulum agar mengahasilkan lulusan yang bermutu dan tetap memiliki sikap social yang baik. Inovasi kebijakan kepala sekolah harus menciptakan sistem pendidikan yang efektif, bermutu, kreatif, inovatif dan berkarakter serta mampu mengadaptasi dan menselaraskan terhadap munculnya perkembangan teknologi yang sangat cepat sebagai dampak dari revolusi industry 4.0. Langkah yang dilakukan kepala sekolah SMA 12 Kota Bandung dalam mengembangkan kurikulum tingkat satuan pendidikan melalui penataan pola pikir terhadap tata kelola kurikulum, perluasan materi sikap sosial dan penguatan proses pembelajaran sikap social peserta didik.

\section{DAFTAR PUSTAKA}

Afifudin dan Beni Ahmad Saebani. (2012). Metode Penelitian Kualitatif. Bandung: Pustaka Setia.

Asmarawati1, Endah, Riyadi, Imam Sujadi. (2016). Proses Integrasi Sikap Sosial dan Spiritual dalam Pembelajaran Matematika Ppda Siswa Kelas VII SMP Negeri di Kecamatan Purwodadi. Jurnal Elektronik Pembelajaran Matematika ISSN: 2339-1685 Vol.4, No.1, hal 58-69 Maret 2016 http://jurnal.fkip.uns.ac.id.

Dunn, William N. (2000). Pengantar Analisis Kebijakan Publik. Yogyakarta: Gajah Mada University Press,, cet. ke-IV, 95-97.

Flurentin, Elia. (2012). Latihan Kesadaran Diri (Self Awareness) dan Kaitannya dengan Penumbuhan Karakter. Jurnal Inspirasi Pendidikan. Vol. 1 No. 1 (Januari) 2012.

Gunawan, Adi W. (2013). Genius Learning Strategy; Petunjuk Praktis untuk Menerapkan Accelarated Learning. Jakarta: PT. Gramedia Pustaka Utama.

Hamdan. (2018). Industri 4.0: Industri Pengaruh Revolusi pada Kewirapor Demi Kemandirian Ekonomi. Jurnal NUSAMBA, Vol. 3 No. 2 (2018).

Ismail, Muhammad Ilyas. (2012). Pendidikan Karakter: Suatu Pendekatan Nilai. Makassar: Alauddin University Press.

Juwita, Elsa Puji, Dasim Budimansyah, Siti Nurbayani. (2014). Peran Media Sosial Terhadap Gaya Hidup SiswA SMA Negeri 5 BANDUNG. Jurnal Sosietas, Vol. 5, No. 1, 2014.

Kartono, Kartini. (2010). Teori Kepribadian. Bandung: CV Mandar Maju. 
Jurnal Pendidikan Pancasila dan Kewarganegaraan

Volume I Nomor 2 (November) 2020

Keke, Febriana Florentina dan Denok Setiawati. (2014). Pengembangan Panduan Pelatihan Tanggung Jawab Sosial Melalui Proses Regulasi Diri Pada Siswa SMP KATOLIK ST. Vincentius Surabaya. Jurnal BK UNESA. Volume 04 Nomor 02 Tahun 2014, 350 - 360.

Kodiran. (2017). Kepala Sekolah Sebagai Tugas Tambahan. Al-Idarah: Jurnal Kependidikan Islam VII (I) (2017).

Koni, Satria MA. (2016). Pengaruh Jejaring Sosial Terhadap Pendidikan Karakter Peserta Didik" (Studi Kasus Di SMKN 1 Bone Raya Kab. Bone Bolango Provinsi Gorontalo. TADBIR : Jurnal Manajemen Pendidikan Islam Volume 4, Nomor 2.

Kusumaningtyas, Lydia Ersta. (2012). Membentuk Sikap Sosial Anak TK Melalui Permainan Kelompok. Widya Wacana: Jurnal Ilmiah, Vol 8, No 1 (2012).

Mulyasa, E. (2010). Kurikulum Berbasis Kompetensi (KBK), Konsep, Karakteristik dan Implementasi. Bandung: Remaja Rosdakarya.

Prasetyo, Banu dan Umi Trisyanti. (2018). Revolusi Industri 4.0 dan Tantangan Perubahan Sosial. Prosiding SEMATEKSOS 3 "Strategi Pembangunan Nasional MenghadapiRevolusiIndustri 4.0".

Rismawanti. (2017). Peningkatan Sikap Sosial Menggunakan Model Active Knowledge Sharing Siswa Kelas V SD N Ngentakrejo The Improvement Of Social Attitude Through Active Knowledge Sharing. Jurnal Pendidikan Guru Sekolah Dasar Edisi 4 Tahun ke-6 2017

Rusyan, A. Tabrani. (2013). Profesionalisme Kepala Sekolah. Jakarta: Gilang Saputra.

Sari, Yuni Maya. (2014). Pembinaan Toleransi Dan Peduli Sosial Dalam Upaya Memantapkan Watak Kewarganegaraan (Civic Disposition) SiswA. JPIS, Jurnal Pendidikan Ilmu Sosial, Volume 23, No. 1, Edisi Juni 2014.

Suryana, Ermis dan Maryamah. (2013). Pembinaan Keberagamaan Siswa Melalui Pengembangan Budaya Agama di SMA Negeri 16 Palembang. Jurnal TA'DIB, Vol. XVIII, No. 02, Edisi Nopember 2013. Sutarno. (2012). Serba-Serbi Manajemen Bisnis. Yogyakarta: Graha Ilmu.

Yeni, Fitra. (2014). Peran Orang Tua dalam Penyediaan Fasilitas Belajar Anak Kelas 1 SD. Jurnal Bimbingan dan Konseling. Vol. 4 (2). Hlm. 1-3. 